\title{
PENGARUH KONSENTRASI NITROGEN DAN FOSFOR TERHADAP POTENSI Pseudomonas PENDEGRADASI ALKILBENZEN SULFONAT LINIAR (LAS)
}

\author{
Suharjono J, Subagja L, Sembiring C, Retnaningdyah, dan IKJW Putra \\ Biology Department, Faculty of Mathematics and Natural Science, Brawijaya University, Malang 65145 \\ Faculty of Biology, Gadjah Mada University, Yogyakarta
}

\begin{abstract}
Linear Alkylbenzene Sulfonate (LAS) concentration over $0.5 \mathrm{mg} / \mathrm{L}$ has toxic effect on organisms in river ecosystem. Some indigenous Pseudomonas strains on detergent polluted river have capacity to degraded LAS. The objective of the research was to study the effect of increasing of nitrogen $(N)$ and phosphorus $(P)$ concentration in minimum mineral medium on growth and LAS biodegradation potency of Pseudomonas strains using batch culture. The experiment was carried out by Randomized Block Design and three replications. Each three milliliter of strain starter contain $10^{8} \mathrm{cell} / \mathrm{ml}$ was inoculated into $27 \mathrm{ml}$ of each media formulation. Each culture was incubated aerobically at $30^{\circ} \mathrm{C}$ on shaker incubator. Amount of bacteria cell and LAS residue concentration were observed on 0, $3^{\text {rd }}$, $6^{\text {th }}, 9^{\text {th }}$ and $12^{\text {th }}$ day incubation. Data was analyzed using variance analyze and followed by Honesty Significance Difference test on $5 \%$ significance level. The result of the research showed that Pseudomonas putida FNCC071, Pseudomonas sp. strain R, and Pseudomonas sp. strain $J$ was capable to degrade LAS about $89.0 \%, 87.0 \%$ and $80.0 \%$ respectively in 12 days incubation. The highest increasing of $N$ and $P$ concentration in media gives the highest potency of bacteria strains to degrade LAS ( $p>0.05)$.
\end{abstract}

Key words: $N$ and P concentration, LAS, Pseudomonas strain, Biodegradation potency

\section{PENGANTAR}

Surfaktan anionik Linear Alkylbenzene Sulfonate (LAS) saat ini dominan digunakan sebagai bahan aktif dalam formulasi deterjen sintetik (Jimenez et al., 1991; Campos-Garcia et al., 1999; Jerabkova et al., 1999; Huang et al., 2000; Schleheck et al., 2000; Sigoillot dan Nguyen 1992). LAS tersebut sejak tahun 1965 secara dominan digunakan dalam formulasi deterjen sintetik karena dapat didegradasi, untuk menggantikan Alkylbenzene Sulphonate bercabang $(A B S)$ yang sulit didegradasi (Lee dan Hong, 1980; Anderson et al., 1990; Marchesi et al., 1994; Schleheck et al., 2004). Konsumsi surfaktan tersebut terus meningkat dari 13 juta ton pada tahun 1977 menjadi 18 juta ton pada 1996. Surfaktan anionik LAS dalam jumlah sekitar 1,5 juta ton per tahun saat ini digunakan dalam formulasi deterjen tersebut (Vidali, 2001). Peningkatan penggunaan deterjen oleh masyarakat telah secara nyata menghasilkan limbah cair domestik yang mengandung LAS dan mencemari ekosistem sungai (Jimenez et al., 1991; Kenzaka et al., 2001). Konsentrasi LAS di ekosistem sungai di kota besar-kota besar yang padat penduduknya khususnya di Indonesia sudah melampaui nilai ambang $0,5 \mathrm{mg} / \mathrm{L}$. Hasil penelitian menunjukkan konsentrasi LAS di air Kali Mas Surabaya pada musim kemarau 2,49-4,65 $\mathrm{mg} / \mathrm{L}$ (Mitakda et al., 2000), sedangkan pada musim penghujan 0,82-1,43 mg/L (Retnaningdyah et al., 1999).
Konsentrasi LAS di air sungai sekitar pemukiman yang sedikit penduduknya antara $0,37-1,14 \mathrm{mg} / \mathrm{L}$ (Arifyanti, 2002) dan di air sungai sekitar pemukiman padat penduduk antara 4,06-8,98 mg/L (Suharjono, 2003). Akumulasi konsentrasi LAS melampaui $0,5 \mathrm{mg} / \mathrm{L}$ bersifat toksik bagi berbagai organisme akuatik (Zeni dan Caligiuri, 1992; Lewis, 1990; Retnaningdyah et al., 2001). LAS pada konsentrasi tersebut dapat membentuk busa sehingga dapat menurunkan estetika lingkungan, serta bila busa tersebut tertiup angin dapat menyebarkan mikrobia patogen (Jimenez et al., 1991; Van Ginkel, 1996). Pencemaran deterjen tersebut merupakan salah satu penyebab punahnya dan turunnya keragaman berbagai organisme di ekosistem sungai serta terganggunya pemanfaatan air sungai untuk berbagai peruntukan bagi manusia.

Bioremediasi merupakan salah satu teknologi yang dapat diterima untuk restorasi lingkungan tercemar dan menurunkan toksisitas polutan tersebut dengan melibatkan aktivitas mikrobia (Halden et al., 1999; Vidali, 2001). Komunitas mikrobia memainkan peran yang sangat penting dalam biodegradasi senyawa pencemar alami maupun yang berasal dari aktivitas manusia, serta mendukung swapurifikasi ekosistem secara alami (Kenzaka et al., 2001). Strain bakteri anggota genus Pseudomonas kosmopolitan dan kelimpahan serta keragamannya predominan di ekosistem sungai (Holder-Franklin et al., 1981), di ekosistem air asin 
(Del Moral et al., 1988) dan di ekosistem tanah rizosfer (Barraquio et al., 1983). Beberapa strain anggota genus Pseudomonas berperan dominan dan berpotensi tinggi dalam menguraikan serta menurunkan toksisitas limbah deterjen yang mengandung bahan aktif LAS (Jimenez et al., 1991; Van Ginkel, 1996; Campos-Garcia et al., 1999; Jerabkova et al., 1999; Schleheck et al., 2000 dan 2004). Beberapa strain bakteri tersebut masing-masing mampu menguraikan LAS sama efektifnya bila dibandingkan dengan biakan campuran berbagai strain anggota genus bakteri yang lain. Oleh karena itu, beberapa strain bakteri tersebut banyak digunakan sebagai agen dalam pengolahan limbah cair domestik yang banyak mengandung deterjen.

Beberapa strain anggota genus Pseudomonas indigenous ekosistem sungai tercemar deterjen memiliki potensi yang lebih tinggi dalam mendegradasi LAS dibandingkan strainstrain dari ekosistem yang belum tercemar (Anderson et al., 1990; Suharjono et al., 2004). Berberapa strain anggota Pseudomonas indigenous ekosistem sungai tercemar detergen di Indonesia memiliki potensi sebagai pendegradasi LAS (Mitakda et al., 2000; Arifyanti 2002; Suharjono et al., 1999; Suharjono 2003; Suharjono et al., 2004). Hasil penelitian Suharjono et al. (2004) menunjukkan bahwa beberapa strain anggota Pseudomonas tersebut memiliki kemampuan pertumbuhan dan potensi biodegradasinya terhadap LAS berkurang setelah inkubasi 72 jam, meskipun residu LAS masih banyak. Oleh karena itu, penelitian ini bertujuan untuk mempelajari pengaruh penambahan konsentrasi senyawa sumber nitrogen $(\mathrm{N})$ dan fosfor $(\mathrm{P})$ dalam media mineral terhadap pertumbuhan dan potensi strain-strain anggota Pseudomonas dalam mendegradasi LAS. Manfaat yang diharapkan dari penelitian ini adalah menemukan suatu usaha alternatif untuk meningkatkan kinerja strain-strain bakteri tersebut dalam mendegradasi dan menurunkan toksisitas LAS, dalam upaya membantu pemerintah mengatasi pencemaran lingkungan.

\section{BAHAN DAN CARA KERJA}

\section{Bahan Penelitian}

Tiga strain bakteri diuji kemampuan tumbuh dan potensi biodegradasinya terhadap LAS yang diberi perlakuan perbedaan konsentrasi senyawa sumber N dan P. Dua strain yaitu Pseudomonas sp. strain J dan R merupakan isolat indigenous ekosistem sungai tercemar deterjen koleksi Laboratorium Mikrobiologi FMIPA Universitas Brawijaya Malang. Strain acuan yang digunakan yaitu $P$. putida FNCC071 diperoleh dari PAU Bioteknologi Universitas Gadjah Mada Yogyakarta. Medium yang digunakan adalah medium mineral menurut He et al. (1998) dengan komposisi senyawa dalam satu liter akuades adalah: $\left(\mathrm{NH}_{4}\right)_{2} \mathrm{SO}_{4} 0,50 \mathrm{~g}$, $\mathrm{MgSO}_{4} .7 \mathrm{H}_{2} \mathrm{O} 0,40 \mathrm{~g} ; \mathrm{Na}_{2} \mathrm{HPO}_{4} .12 \mathrm{H}_{2} \mathrm{O} 9,65 \mathrm{~g} ; \mathrm{KH}_{2} \mathrm{PO}_{4}$ 2,65; serta trace element $\mathrm{FeCl}_{2} .6 \mathrm{H}_{2} \mathrm{O} 20.0 \mathrm{~g} ; \mathrm{CaCl}_{2} . \mathrm{H}_{2} \mathrm{O}$ $10,0 \mathrm{~g} ; \mathrm{CuSO}_{4} .5 \mathrm{H}_{2} \mathrm{O} \mathrm{0,03} \mathrm{g} ; \mathrm{MnCl}_{2} .4 \mathrm{H}_{2} \mathrm{O} 0,05 \mathrm{~g}$; dan $\mathrm{ZnSO}_{4} .7 \mathrm{H}_{2} \mathrm{O} 0,10 \mathrm{~g}$.

\section{Pembuatan Starter}

Masing-masing strain bakteri uji dari biakan stok diremajakan dalam tabung reaksi berisi medium miring Pseudomonas Agar F Base yang mengandung $10 \mathrm{mg} / \mathrm{L}$ LAS. Bakteri tersebut diinkubasikan secara aerobik pada suhu $30{ }^{\circ} \mathrm{C}$ selama 24 jam. Setiap strain tersebut diaklimatisasikan empat kali dalam medium mineral menurut He et al. (1998) dengan 10 mg/L LAS sebagai satusatunya sumber karbon. Pada awal aklimatisasi, setiap strain diambil satu ose penuh koloni dari medium agar kemudian diinokulasikan ke dalam $30 \mathrm{ml}$ medium mineral yang mengandung sumber karbon $10 \mathrm{mg} / \mathrm{L}$ LAS. Biakan tersebut diikubasikan secara aerobik pada suhu $30^{\circ} \mathrm{C}$ selama tujuh hari. Proses aklimatisasi berikutnya dilakukan dengan cara setiap strain yang sudah diaklimatisasi kemudian diambil tiga mililiter dan diinokulasikan ke dalam $27 \mathrm{~mL}$ medium mineral yang sama dan diinkubasikan seperti aklimatisasi pertama (Lee dan Hong, 1980; Anderson et al., 1990).

Strain-strain bakteri yang sudah diaklimatisasi dibuat strarter dengan cara diambil lima mililiter kemudian diinokulasikan ke dalam $95 \mathrm{ml}$ medium mineral dengan sumber karbon glukosa lima persen dan diperkaya 0,03\% ekstrak khamir. Setiap biakan strain tersebut diinkubasikan secara aerobik dalam inkubator kocok dengan kecepatan $120 \mathrm{rpm}$. Selama inkubasi setiap satu jam dihitung jumlah sel bakteri menggunakan Spectronic 501 pada panjang gelombang $500 \mathrm{~nm}$. Biakan setiap strain yang berada dalam fase pertumbuhan logaritmik dengan jumlah sel sekitar $10^{8} \mathrm{sel} / \mathrm{ml}$ digunakan sebagai biakan starter dalam uji pertumbuhan dan potensinya dalam mendegradasi LAS.

\section{Uji Biodegradasi Surfaktan Anionik LAS}

Percobaan pengaruh berbagai konsentrasi $\mathrm{N}$ dan $\mathrm{P}$ dalam media mineral dengan sumber karbon $35 \mathrm{mg} / \mathrm{L}$ LAS terhadap pertumbuhan dan potensi biodegradasi setiap strain uji terhadap LAS dilakukan dengan rancangan acak kelompok dan tiga ulangan. Pengelompokan dalam percobaan ini didasarkan pada ulangan percobaan yang dilakukan dalam waktu yang berbeda. Hal tersebut memungkinkan terjadinya variasi jumlah sel dan konsentrasi LAS setiap ulangan pada awal percobaan. Perlakuan variasi konsentrasi senyawa sumber $\mathrm{N}$ dan $\mathrm{P}$ dalam media mineral disajikan dalam Tabel 1. 
Tabel 1. Komposisi konsentrasi $\mathrm{N}$ dan $\mathrm{P}$ dalam media mineral

\begin{tabular}{|c|c|c|c|c|c|c|}
\hline \multirow{2}{*}{ No } & \multirow{2}{*}{ Senyawa } & \multicolumn{5}{|c|}{ Berat Senyawa (g/1000 mL akuades) } \\
\hline & & mms 1 & mms 2 & mms 3 & mms 4 & mms 5 \\
\hline 1 & LAS & 0,035 & 0,035 & 0,035 & 0,035 & 0,035 \\
\hline 2 & $(\mathrm{NH} 4)_{2} \mathrm{SO}_{4}$ & 0,5 & 1 & 1,5 & 0,5 & 1,5 \\
\hline 3 & $\mathrm{MgSO}_{4} \cdot 7 \mathrm{H}_{2} \mathrm{O}$ & 0,4 & 0,4 & 0,4 & 0,4 & 0,4 \\
\hline 4 & $\mathrm{Na}_{2} \mathrm{HPO}_{4} \cdot 12 \mathrm{H}_{2} \mathrm{O}$ & 9,65 & 9,65 & 9,65 & 12,06 & 14,48 \\
\hline 5 & $\mathrm{KH}_{2} \mathrm{PO}_{4}$ & 2,65 & 3,09 & 2,65 & 2,83 & 2,65 \\
\hline \multirow[t]{6}{*}{6} & Trace element $(1 \mathrm{ml})$ : & & & & & \\
\hline & a. $\mathrm{FeCl}_{2} \cdot 6 \mathrm{H}_{2} \mathrm{O}$ & 20 & 20 & 20 & 20 & 20 \\
\hline & b. $\mathrm{CaCl}_{2} \cdot \mathrm{H}_{2} \mathrm{O}$ & 10 & 10 & 10 & 10 & 10 \\
\hline & c. $\mathrm{CuSO}_{4} .5 \mathrm{H}_{2} \mathrm{O}$ & 0,03 & 0,03 & 0,03 & 0,03 & 0,03 \\
\hline & d. $\mathrm{MnCl}_{2} .4 \mathrm{H}_{2} \mathrm{O}$ & 0,05 & 0,05 & 0,05 & 0,05 & 0,05 \\
\hline & e. $\mathrm{ZnSO}_{4} .7 \mathrm{H}_{2} \mathrm{O}$ & 0,1 & 0,1 & 0,1 & 0,1 & 0,1 \\
\hline
\end{tabular}

Percobaan ini dilakukan dalam sistem biakan tertutup (batch culture). Suspensi starter masing-masing strain bakteri dengan jumlah sekitar $10^{8} \mathrm{sel} / \mathrm{ml}$ diambil tiga mililiter dan diinokulasikan ke dalam $27 \mathrm{ml}$ setiap media mineral sederhana yang mengandung $35 \mathrm{mg} / \mathrm{L}$ LAS. Setiap botol biakan merupakan satu perlakuan dan digunakan untuk satu kali pengamatan. Setiap biakan tersebut kemudian diinkubasikan secara aerobik dalam inkubator kocok kecepatan $120 \mathrm{rpm}$ pada suhu $30^{\circ} \mathrm{C}$. Parameter jumlah sel dan konsentrasi residu LAS diamati pada umur inkubasi $0,3,6,9$, dan 12 hari. Jumlah sel dihitung berdasarkan densitas optiknya menggunakan spektrofotometer spectronic 501 pada panjang gelombang $500 \mathrm{~nm}$. Konsentrasi residu LAS diukur dengan metode Methylene Blue Active Substance (MBAS) (Clesceri et al., 1989). Data jumlah sel dan konsentrasi residu LAS dilakukan analisis ragam dan uji Beda Nyata Jujur (BNJ) dengan tingkat signifikansi 5\% menggunakan program SPSS for MS Windows Release 10.

\section{HASIL}

Hasil uji potensi biodegradasi LAS masing-masing strain menunjukkan ketiga strain uji memiliki potensi paling tinggi dalam medium mineral dengan penambahan konsentrasi senyawa sumber $\mathrm{N}$ dan $\mathrm{P}$ yang paling tinggi (mms 5, Tabel 1.). Dalam medium tersebut selama inkubasi 12 hari, P. putida FNCC071 mampu mendegradasi LAS paling tinggi $89 \%$ yaitu dari $34,20 \mathrm{mg} / \mathrm{L}$ menjadi $3,79 \mathrm{mg} / \mathrm{L}$ (Gambar 1). Dalam medium dan waktu yang sama Pseudomonas sp. strain J mampu mendegradasi LAS sebesar 80\% yaitu dari $39 \mathrm{mg} / \mathrm{L}$ menjadi 7,15 mg/L (Gambar 2), sedangkan Pseudomonas sp. strain R mampu mendegradasi LAS sebesar $87 \%$ yaitu dari $32,87 \mathrm{mg} / \mathrm{L}$ menjadi $3,39 \mathrm{mg} / \mathrm{L}$ (Gambar 3). P. putida FNCC071, Pseudomonas sp. strain J, dan strain R mengalami peningkatan potensi dalam mendegradasi LAS secara berturut-turut sebesar $41 \%, 26 \%$, dan $25 \%$ setelah diberi perlakuan aklimatisasi dan penambahan konsentrasi senyawa sumber $\mathrm{N}$ sebesar $100 \%$ dan P sebesar 36\%.

Semua strain bakteri uji dalam medium mineral dengan sumber karbon $35 \mathrm{mg} / \mathrm{L}$ LAS serta variasi konsentrasi N dan P menunjukkan pertumbuhan jumlah sel sampai umur inkubasi 12 hari $(\mathrm{p}<0,05)$. P. Putida FNCC071 dalam medium mineral dengan konsentrasi $0,1 \% \mathrm{~N}$ dan $1,3 \% \mathrm{P}$ setelah 12 hari inkubasi mengalami pertumbuhan jumlah sel paling tinggi sebesar $3318 \%$, yaitu dari $0,94 \times 10^{8}$ $\mathrm{sel} / \mathrm{mL}$ menjadi $32,07 \times 10^{8} \mathrm{sel} / \mathrm{mL}$ (Gambar 4). Dalam

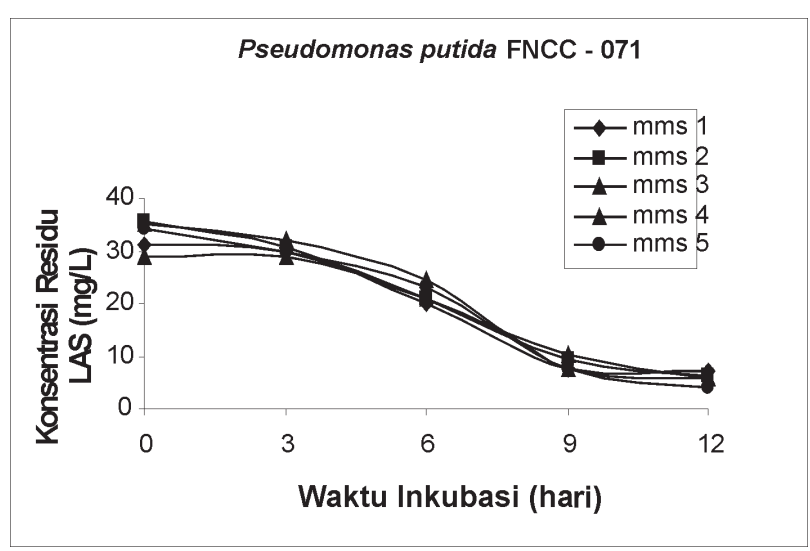

Gambar 1. Potensi biodegradasi P. Putida FNCC071 terhadap LAS 
Pseudomonas sp. strain J

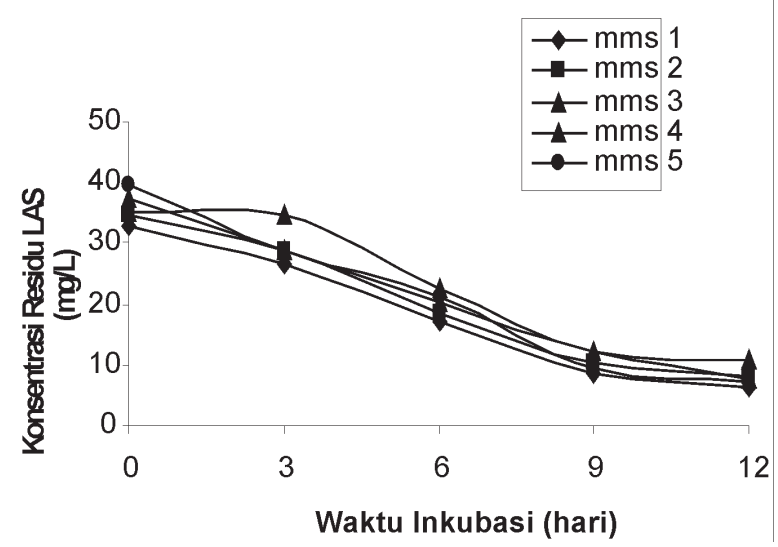

Gambar 2. Potensi biodegradasi Pseudomonas sp. Strain J terhadap LAS

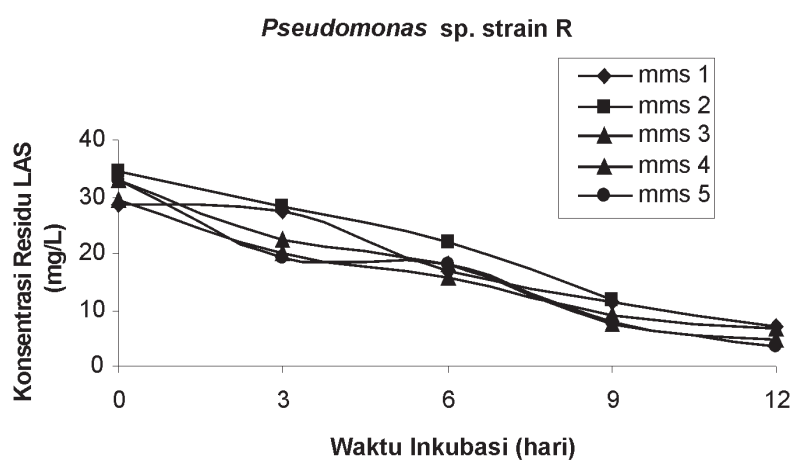

Gambar 3. Potensi biodegradasi Pseudomonas sp. Strain R terhadap LAS

Pseudomonas putidaFNCC - 071

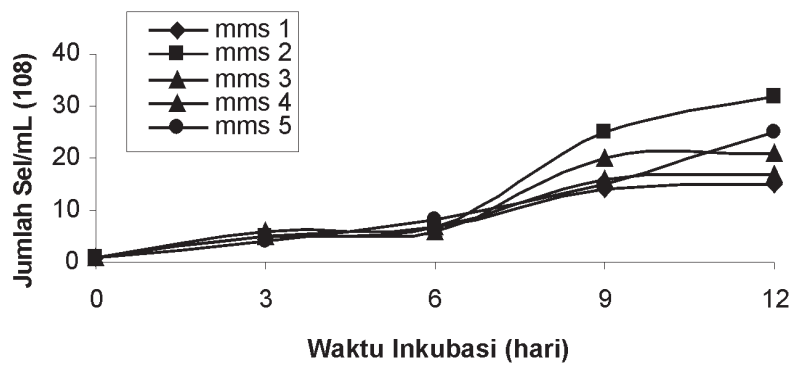

Gambar 4. Pertumbuhan sel P. Putida FNCC071
Pseudomonas sp. strain J

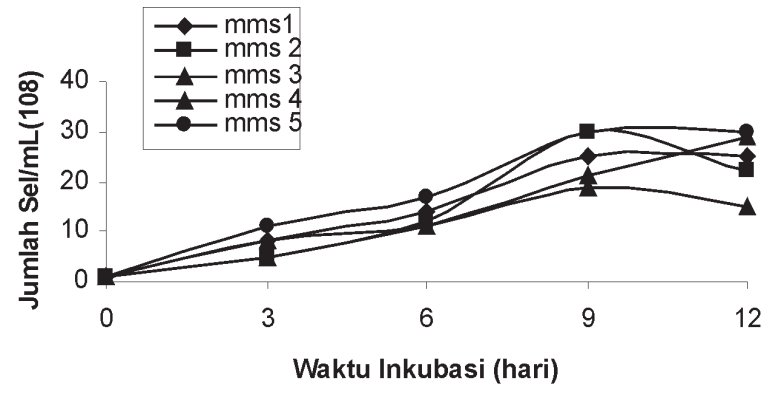

Gambar 5. Pertumbuhan sel Pseudomonas sp. Strain J

Pseudomonas sp. strain R

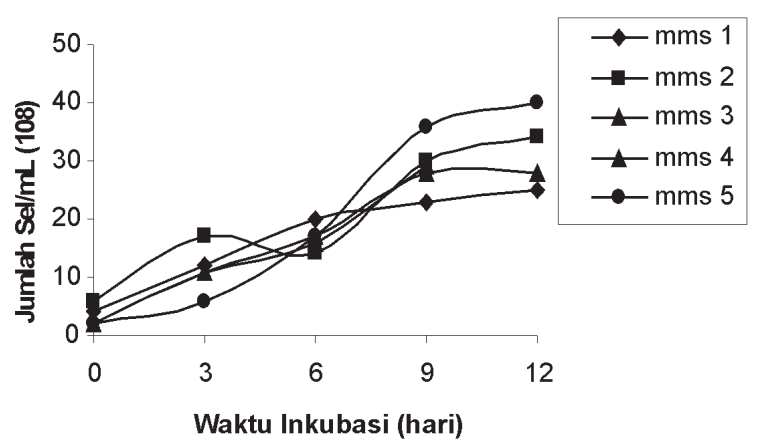

Gambar 6. Pertumbuhan Pseudomonas sp. Strain R

waktu tersebut dan dalam medium dengan konsentrasi $0,15 \% \mathrm{~N}$ dan $1,85 \%$ Pseudomonas sp. strain J jumlah sel tumbuh paling tinggi sebesar $20,27 \%$ yaitu dari $1,42 \times 10^{8} \mathrm{sel} / \mathrm{mL}$ menjadi 30,21 $\times 10^{8} \mathrm{sel} / \mathrm{ml}$ (Gambar 5), sedangkan Pseudomonas sp. strain R pertumbuhannya paling tinggi sebesar $1591 \%$ yaitu dari $1,99 \times 10^{8} \mathrm{sel} / \mathrm{ml}$ menjadi 39,36 × $10^{8} \mathrm{sel} / \mathrm{mL}$ (Gambar 6). Masing-masing bakteri P. putida FNCC071, Pseudomonas sp. strain J, dan strain $\mathrm{R}$ tersebut setelah diberi perlakuan aklimatisasi dan penambahan konsentrasi senyawa sumber $\mathrm{N}$ sebesar $100 \%$ dan P $36 \%$ mengalami peningkatan perumbuhan secara beturut-turut sebesar 3287\%, 1926\%, dan $1510 \%$. Peningkatan konsentrasi nitrogen saja dapat meningkatkan pertumbuhan strain, tetapi peningkatan konsentrasi P saja tidak berpengaruh terhadap pertumbuhan sel. Peningkatan konsentrasi kedua unsur tersebut lebih besar pengaruhnya dalam meningkatkan pertumbuhan ketiga strain. Variasi peningkatan konsentrasi $\mathrm{N}$ dan $\mathrm{P}$ yang tidak besar tersebut juga menyebabkan variasi peningkatan pertumbuhan ketiga strain relatif kecil $(p>0,05)$. 


\section{PEMBAHASAN}

Perlakuan variasi konsentrasi $\mathrm{N}$ dan $\mathrm{P}$ dalam medium mineral tersebut pengaruhnya tidak besar $(p>0,05)$ terhadap potensi semua strain dalam biodegradasi LAS. Hal ini disebabkan variasi peningkatan konsentrasi $\mathrm{N}$ dan $\mathrm{P}$ tersebut relatif kecil. Perlakuan yang menyebabkan variasi yang nyata terhadap residu konsentrasi LAS adalah perbedaan strain dan umur inkubasi, meskipun kedua faktor tersebut pengaruhnya sendiri-sendiri. Adanya perlakuan aklimatisasi strain uji sebelum digunakan serta penambahan konsentrasi $\mathrm{N}$ dan $\mathrm{P}$ dapat meningkatkan potensi biodegradasi strain terhadap LAS bila dibandingkan dengan hasil penelitian Suharjono et al. (2004).

Menurut Anderson et al. (1990) dan Marchesi et al. (1994) strain-strain bakteri yang telah teradaptasi dalam ekosistem tercemar deterjen memiliki potensi biodegradasi terhadap LAS lebih tinggi dibandingkan strain-strain indigenous di ekosistem tidak tercemar. Schleheck et al. (2000) menyatakan bahwa oksidasi amonium dapat meningkatkan biodegradasi strain-strain bakteri terhadap LAS. Dijelaskan bahwa proses bioremediasi ekosistem yang tercemar hidrokarbon sangat lambat apabila tidak ada biostimulasi berupa penambahan nutrien. Ada suatu korelasi yang positif yaitu dengan biostimulasi atau penambahan $\mathrm{N}$ dan $\mathrm{P}$ dapat meningkatkan laju metabolisme dan pertumbuhan mikrobia indigenous pengurai polutan (Margesin dan Skinner, 1998). Dalam kondisi media dengan sumber karbon yang sesuai dan mencukupi tetapi terjadi keterbatasan suplai nitrogen dan fosfor, kebanyakan bakteri dapat mengakumulasi sejumlah senyawa polimer sebagai cadangan makanan dalam sel, seperti glikogen, lipid atau Polihidroksibutirat (PHB). Bakteri tersebut dalam sistem biakan tertutup pertumbuhannya menjadi lambat (Wanner dan Egli, 1990).

Bila dibandingkan dengan kemampuan Pseudomonas C12B (Jerabkova et al., 1999), maka potensi biodegradasi LAS oleh kedua strain hasil isolasi tersebut masih jauh lebih rendah. Hal ini disebabkan oleh beberapa faktor antara lain: a) perbedaan strain yang digunakan, dan b) sistem uji biodegradasi yang berbeda. Dalam penelitian ini uji biodegradasi LAS dilakukan dalam sistem tertutup sehingga hasil metabolit yang terakumulasi dalam media dapat menghambat pertumbuhan sel bakteri, sedangkan pada penelitian Jerabkova et al. (1999) dilakukan dengan sistem biakan kontinu dan diberi substrat untuk pembentukan biofilm. Menurut hasil penelitian tersebut, Pseudomonas C12B mampu mendegradasi secara LAS sebesar 98\% sampai konsentrasi $600 \mathrm{mg} / \mathrm{L}$ dan kemampuannya lebih tinggi dalam bioreaktor yang diberi substrat pendukung pembentuk biofilm dibanding tanpa substrat.

Halden et al. (1999) menunjukkan bahwa P. pseudoalcaligenes POB310 tidak mampu mendegradasi asam phenoksibenzoat bila media tidak ditambah nutrien lain, bahkan strain tersebut tidak dapat bertahan hidup. Dijelaskan pula bahwa penambahan fosfor saja hanya sedikit meningkatkan pertumbuhan sel, sebaliknya penambahan $\mathrm{N}$ dan $\mathrm{P}$ secara bersamaan dapat meningkatan biodegradasi senyawa tersebut seiring dengan peningkatan jumlah sel. Bell et al. (1982) juga menunjukkan bahwa peningkatan konsentrasi nitrogen dalam sistem biakan kontinu dapat meningkatkan pertumbuhan sel. Menurut Vidali (2001) nitrogen, fosfor dan karbon merupakan unsurunsur yang penting sebagai penyusun komponen sel serta memungkinkan mikrobia mampu membentuk enzim-enzim yang diperlukan untuk mendegradasi pencemar.

Pertumbuhan sel dan berkurangnya konsentrasi LAS dalam media mineral menunjukkan bahwa strain-strain bakteri tersebut mampu mendegradasi dan memanfaatkan LAS sebagai sumber karbon, energi atau belerang untuk pertumbuhannya. Beberapa strain anggota Pseudomonas diketahui memiliki operon yang berbeda, masing-masing menyandikan sistem enzim yang berbeda dan bekerja dalam metabolisme gugus spesifik surfaktan tersebut. Operonoperon tersebut antara lain operon alk yang menyadikan sistem enzim pemecah gugus alkil (Van Beilen et al., 1992), operon pWWO (TOL) menyandikan sistem enzim yang bekerja dalam metabolisme cincin benzen (Horn et al., 1991; Wackett; 2003) serta operon ssu yang menyandikan sistem enzim yang terlibat dalam desulfonolisis gugus sulfonat (Kahnert et al., 2000; Schleheck et al., 2003). Menurut Suharjono et al. (1999) adanya biodegradasi parsial LAS secara nyata dapat menurunkan toksisitasnya terhadap berbagai organisme akuatik.

Berdasarkan hasil penelitian tersebut dapat disimpulkan bahwa peningkatan konsentrasi N 100\% dan P 36\% dalam medium mineral dapat meningkatkan pertumbuhan sel P. putida FNCC071 yang paling tinggi sebesar $3318 \%$. P. putida $\mathrm{FNCC} 071$ juga memiliki potensi paling tinggi sebesar $89 \%$ dalam mendegradasi LAS.

\section{KEPUSTAKAAN}

Anderson DJ, Day MJ, Russel NS dan White GF, 1990. DieAway Kinetic Analysis of the Capacity of Epilithic and Planktonic Bacteria from Clean and Polluted River Water to Biodegradate Sodium Dodecyl Sulfate. Appl. Environ. Microbiol. 56: 758-763. 
Arifyanti NT, 2002. Pengaruh Limbah Deterjen Terhadap Kelimpahan Komunitas Bakteri Pseudomonas sp. Skripsi. Jurusan Biologi FMIPA Universitas Brawijaya. Malang.

Barraquio WL, Ladha JK dan Watanabe I, 1983. Isolation and Identification of N2 Fixing Pseudomonas Associated with Wetland Rice. Can. J. Microbiol. 29: 867-873.

Bell CR, Holder-Franklin MA dan Franklin M, 1982. Seasonal Fluctuation in River Bacteria as Measured by Multivariate Statistical Analysis of Continuous Culture. Can. J. Microbiol. 28: 959-975.

Campos-Garcia J, Esteve A, Vasquez R, Ramos JL dan SoberonChavez G, 1999. The Branched-Chain Dodecylbenzene Sulfonate Degradation Pathway of Pseudomonas aeruginosa W51D Involves a Novel Route for Degradation of the Surfactant Lateral Alkyl Chain. Appl. Environ. Microbiol. 65(8): 3730-3734.

Clesceri LS, Arnold EG, Trussel RR dan Mory AHF, 1989. Standard Methods for The Examination of Water and Waste Water. $17^{\text {th }}$ ed. APHA, AWWA and WPLF. Washington.

Del Moral A, Prado B, Quesada E, Garcia T, Ferrer R dan RamosComenzana, 1988. Numerical Taxonomy of Moderately Halophylic Gram Negative Rods from an Inland Saltern. J. Gen. Microbiol. 134: 733-741.

Halden RU, Tepp SM, Halden BG dan Dwyer DF, 1999. Degradation of 3-Phenoxybenzoic Acid in Soil by Pseudomonas pseudoalcaligenes POB310(pPOB) and Two Modified Pseudomonas Strains. Appl. Environ. Microbiol. 65(8): 3354-3359.

He W, Weidong T, Guang Z, Gup-Qiang C dan Zengming Z, 1998. Production of Novel Polyhydroxyalkanoates by Pseudomonas stutzeri 1317 from Glucose and Soybean Oil. FEMS Microbiol Lett. 169: 45-49.

Holder-Franklin MA, Thorpe A dan Carmier CJ, 1981. Comparison of Numerical Taxonomy and DNA-DNA Hybridization in Diurnal Studies of River Bacteria. Can. J. Microbiol. 27: 1165-1183.

Horn JM, Harayama S. dan Timmis KH, 1991. DNA Sequence Determination of the TOL Plasmid (pWWO) xyl GFS genes of Pseudomonas putida: Implications for the Evolution of Aromatic Catabolism. Mol. Microbiol. 5(10): 2459-2474.

Huang H, Ellis TG dan Kaiser SK, 2000. Extant Biodegradation Testing with Linear Alkylbenzene Sulfonate in Laboratory and Field Activated Sludge Systems. WEFTEC, Water Evironmental Federation.

Jerabkova H, Kralova B dan Nahlik J, 1999. Biofilm of Pseudomonas C12B on Glass Support as Catalytic Agent for Continuous SDS Removal. Int. Biodet. Biodeg. 44: 233-241.

Jimenez L, Breen A, Thomas N, Federle TW dan Saylor GS, 1991. Mineralization of Linear Alkylbenzene Sulfonate by a Four-member Aerobic Bacterial Consortium. Appl. Environ. Microbiol. 57(5): 1566-1569.

Kahnert A, Vermeij P, Wietek C, James P, Leisinger T dan Kertesz MA, 2000. The ssu Locus Plays a Key Role in
Organosulphure Metabolism in Pseudomonas putida S-313. J. Bacteriol. 182(10): 2869-2878.

Kenzaka T, Yamaguci N, Prapagde B, Mikami E dan M Nasu, 2001. Bacterial Community Composition and Activity in Urban Rivers in Thailand and Malaysia. J. Health Sci. 47(4): 353-361.

Lee HJ dan Hong SW, 1980. Biodegradation of and Comparison of Adaptability to Detergents. Kor. J. Microbiol. 18(4): 153-160.

Lewis MA, 1990. Chronic Toxicity of Surfactants and Detergent Builders to Algae, A Review and Risk Assesment. Ecotox. Environ. Saf 20: 123-140.

Marchesi SR, Owen SA, White GF, House WA dan Russel NJ, 1994. SDS-Degrading Bacteria Attach to Riverine Sediment in Response to the Surfactant or its Primary Biodegradation Product Dodecan-1-ol. Microbiology 140: 2999-3006.

Margesin R dan Schinner F, 1998. Low Temperature Bioremediation of a Wastewater Contaminated with Anionic Surfactants and Fuel Oil. Appl. Microbiol. Biotechnol. 49: 482-486.

Mitakda B, Prayitno, Suharjono dan Retnaningdyah C, 2000. Perancangan dan Pemodelan Usaha Peningkatan Purifikasi Sungai Brantas Hilir. Natural 4(2): 38-49.

Retnaningdyah C, Samino S, Suharjono, Doddy I dan Prayitno, 1999. Uji Toksisitas Akut Surfaktan Deterjen LAS dan ABS terhadap beberapa Gastropoda Sungai. Natural 3(2): 63-74.

Retnaningdyah C, S. Samino, Suharjono, M. Hadi dan Prayitno, 2001. Pengaruh Surfaktan Deterjen (ABS dan LAS) terhadap Kemampuan Regenerasi Planaria (Dugesia trigina). Natural 5: 21-26.

Schleheck D, Dong W, Denger K, Heinze E dan Cook AM, 2000. An Alfa Proteobacterium Converts Linear Alkylbenzenesulfonate Surfactants into Sulphophenylcarboxylates and Linear Alkylbiphenyetherdisulfonate Surfactants into Sulfodiphenylethercarboxylates. Appl. Environ. Microbiol. 66(5): 1911-1916.

Schleheck D, Lechner M, Schonemberger R, Suter MJF dan Cook AM, 2003. Desulfonation and Degradation of the Disufodiphenilethercarboxylates from Linear Alkyldiphenyletherdisulfonate Surfactant. Appl. Environ. Microbiol. 69(2): 928-944.

Schleheck D, Knepper TP, Fischer K dan Cook AM, 2004. Mineralization of Individual Congeners of Linear Alkylbenzenesulfonate by Defined Pairs of Heterotrophic Bacteria. Appl. Environ. Microbiol. 70 (7): 4053-4063.

Sigoillot J dan Nguyen M, 1992. Complete Oxidation of Linear Alkylbenzene Sulfonate by Bacteria Communities Selected from Coastal Seawater. Appl. Environ. Microbiol. 58: 1308-1312.

Suharjono B, Mitakda, Retnaningdyah C, Prayitno dan Harlin M, 1999. Biodegradasi dan Reduksi Toksisitas Surfaktan Deterjen dalam Media Air Kali Mas Surabaya. Jurusan Biologi FMIPA, Universitas Brawijaya, Malang.

Suharjono. 2003. Distribusi Vertikal dan Keragaman Pseudomonas Pengurai LAS di Ekosistem Sungai Perumahan Sawojajar 
I Malang. Jurusan Biologi, FMIPA, Universitas Brawijaya, Malang.

Suharjono T, Ardyati U, Marwati, 2004. Seleksi Strain Bakteri Anggota Genus Pseudomonas Pengurai LAS (Linear Alkylbenzene Sulfonate) Berdasarkan Uji Potensi dan Analisis DNA Plasmid. Research Grant TPSDP Jurusan Biologi FMIPA Universitas Brawijaya Malang.

Van Beilen, JB, Eggink G, Enesquist H, Boss R dan Witholt B, 1992. DNA Sequence Determination and Functional Characterization of the OCT-plasmid-encoded alk JKL genes of Pseudomonas oleovorans. Mol. Microbiol. 6(21): 3121-3136.
Van Ginkel CG, 1996. Complete Degradation of Xenobiotic Surfactants by Consortia of Aerobic Microorganism. Biodegradation 7: 151-164.

Vidali M, 2001. Bioremediation. An Overview. Pure Appl. Chem. 73(7): 1163-1172.

Wackett L, 2003. Pseudomonas putida a Versatile Biocatalyst. Nat. Biotechnol. 21 (2): 136-138.

Wanner U dan T Egli, 1990. Dynamics of Microbial Growth and Cell Composition in Batch Culture. FEMS Microbiol. Rev. 75: 19-44.

Zeni C dan Caligiuri AS, 1992. Morphological and Ultrastructural Change Induced by sub Lethal Concentration of an Anionic Detergent on Ictalurus sp. Barbel Taste Buds. Microbios 69: 1-52. 